\title{
A nemszteroid típusú gyulladáscsökkentő szerek kockázatáról. Fókuszban az aceclofenac
}

\author{
FARSANG CSABA
}

\begin{abstract}
A nemszteroid típusú gyulladáscsökkentők (NSAID) az orvoslásban a leggyakrabban alkalmazott szerek közé tartoznak. Ennek ellenére számos tanulmányban hangsúlyozták, hogy az NSAID-ok károsíthatják nemcsak a gastrointestinalis $(\mathrm{Gl})$, hanem a cardiovascularis (CV) rendszert is, növelhetik a vérnyomást, a coronariaesemények (angina, myocardiuminfarktus) és a stroke gyakoriságát, emellett vesekárosodást is okozhatnak. A National Institute for Health and Care Excellence (NICE) nem talált bizonyítékot arra, hogy az NSAID-ok alkalmazása fokozná a Covid-19 kockázatát, vagy rontana a Covid-19-ben szenvedó betegek állapotán. Az egyes hatóanyagok nemkívánatos hatásainak gyakorisága és súlyossága azonban jelentős eltéréseket mutat. Sokáig úgy tûnt, hogy az NSAID-ok fokozódó GI kockázata arányban van a COX-1/COX-2 szelektivitással, a cardiovascularis kockázat pedig a COX-2/COX-1 szelektivitással, az újabb adatok azonban ezt nem támasztják alá egyértelmúen. A rendelkezésre álló irodalom alapján, a gastrointestinalis és a cardiovascularis nemkívánatos eseményeket tekintve, az aceclofenac mellékhatásprofilja az NSAID-ok között a legkedvezóbbnek túnik.
\end{abstract}

nemszteroid gyulladásgátlók, COX-1/COX-2 szelektivitás, nemkívánatos mellékhatások, aceclofenac

\author{
RISK OF NONSTEROIDAL \\ ANTIINFLAMMATORY DRUGS. \\ FOCUS ON ACECLOFENAC
}

Nonsteroidal antiinflammatory drugs (NSAIDs) are among the most frequently used pharmaceuticals. Nevertheless, a number of studies emphasized that NSAIDs were damaging not only the gastrointestinal $(\mathrm{Gl})$, but also the cardiovascular (CV) system, could increase the blood pressure, the frequency of coronary events (angina, myocardial infarction) and stroke incidence, as well as they might deteriorate renal functions. The National Institute for Health and Care Excellence (NICE) did not find evidence that administering NSAIDs could increase the risk of developing COVID-19 or worsened the condition of COVID-19 patients. However, unwanted effects of specific drugs differ substantially in their occurrence and seriousness as well. It seemed to be for a long time that the NSAIDs provoked higher GI-risk was closely related to the COX1/COX2 selectivity, like the cardiovascular $(\mathrm{CV})$ risk to the COX2/COX1 selectivity, however, the recent data did not prove it clearly. Based on the available literature while pondering the gastrointestinal and cardiovascular adverse events, among all NSAIDs the aceclofenac profile seemed to be the most favourable.

\section{nonsteroidal antiinflammatory drugs, COX1-/COX2 selectivity, unwanted side effects, aceclofenac}

prof. dr. FARSANG Csaba (levelezési cím/correspondence):

Szent Imre Egyetemi Oktatókórház/Szent Imre University Teaching Hospital; Semmelweis Egyetem, Farmakológia és Farmakoterápiás Intézet/Semmelweis University, Department of Pharmacology and Therapeutics; H-1115 Budapest, Tétényi u. 12-16. E-mail: hunghyp@t-online.hu

Érkezett: 2020. október 26. Elfogadva: 2020. október 30.

https://doi.org/10.33616/lam.30.047

A nemszteroid gyulladáscsökkentők (NSAID) a leggyakrabban alkalmazott szerek a világon, sok közülük szabadon megvásárolható a gyógyszertárban. Ennek jelentőségét aláhúzza az a tapasztalat, hogy a cardiovascularis betegségek kockázata az életkorral nő, valamint a reumatikus betegségeké is, és az NSAID-ok kontroll nélküli alkalmazása a CV betegségek kockázatát ebben a betegcsoportban tovább növelheti. A helyzetet súlyosbítja az a tapasztalat, hogy a kezelőorvost a betegek erről gyakran nem tájékoztatják, így az orvosok az NSAID-ok 
interakcióit (például RAS-gátlókkal, diuretikumokkal, $\beta$-blokkolókkal, bizonyos thrombocytaaggregációt gátló szerekkel) ezekben a betegekben nem ismerik fel.

Az NSAID-ok hatásmechanizmusát a korábbi közlemények részletesen összefoglalták (1-7), ezért itt csak a legfontosabb adatokat ismertetem. A hatás fô eleme a ciklooxigenáz (COX) enzim gátlása. Ez az enzim vesz részt olyan anyagok szintézisében, amelyek fontos szerepet játszanak a különböző szervek gyulladásos folyamataiban és a fájdalom patomechanizmusában. Az NSAID-ok tehát a gyulladásgátlás mellett fájdalomcsillapító hatásúak is.

Régóta ismeretes, hogy a COX enzimnek három fontos fajtája van: a COX-1, a COX-2 és a COX-3.

A COX-1 enzim konstitutív, elsődleges feladata a sejt normális múködéséhez szükséges prosztaglandinok (PG) szintézise, melyek fontosak a gyomornyálkahártya, a vese homeosztázisának fenntartásában.

A COX-2 zömmel gyulladásokban indukálódó enzim, mely bizonyos növekedési faktorok, endotoxinok és citokinek szintéziséhez szükséges. Expresszálódik tumorokban, diabetesben, ezeken kívül kimutatták agyban, vesében, reprodukciós szervekben és a csontokban is. Szabályozza az angiogenesist (vascularis proliferációt) a gyulladásos ízületekben. Az általa szintetizált PG-k részt vesznek a fájdalom és a gyulladás patomechanizmusában. Az indukcióját a kortikoszteroidok gátolják.

A COX-1 és a COX-2 enzimek szerkezetét vázlatosan az 1. ábra mutatja.

A COX-3 a központi idegrendszerben mutatható ki, ez a COX-1 hasítási variánsa (az intron 1 retenciójával a mRNS-ben). Ezt az enzimet az acetaminophen (paracetamol) és az antipyrin

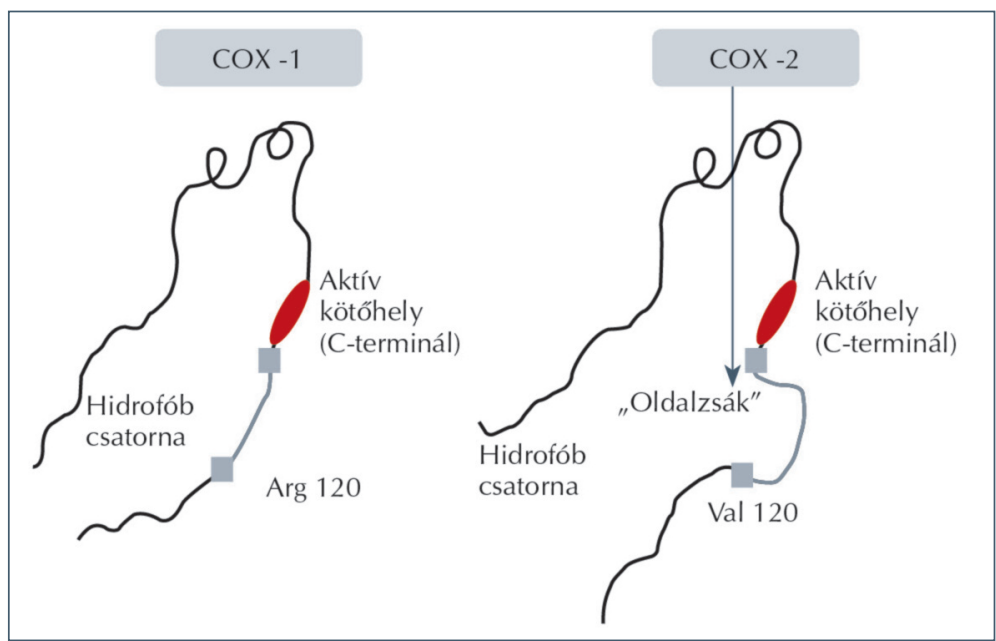

1. ábra. A ciklooxigenáz izoenzimek struktúrája

\section{RÖVIDÍTÉSEK}

COX: ciklooxigenáz

$\mathrm{CV}$ : cardiovascularis

GI: gastrointestinalis

NICE: National Institute of Clinical Excellence

NSAID: nemszteroid típusú gyulladáscsökkentő

szerek

OA: osteoarthritis

PG: prosztaglandinok

RA: rheumatoid arthritis

TXA: tromboxán

VCAM, ICAM: adhéziós molekulák

(phenazonum) gátolja. Ezeknek a szereknek enyhe COX-1- és COX-2-gátló hatása is van, ez is magyarázhatja a fájdalom- és lázcsillapító hatásukat, de ehhez hozzájárul a központi idegrendszerben levô fájdalomérzô mechanizmusok gátlása is. Számos különbözô kémiai struktúrájú szert állítottak elő (2. ábra). A különböző NSAID-ok eltérô erôsséggel (affinitás) és szelektivitással kötődnek e két enzimhez (3. ábra).

A COX-1/COX-2 in vitro meghatározott szelektivitásnak szerepe van néhány nemkívánatos hatásban. A COX-2-re szelektívebb NSAID-ok (melyeket az elsô ilyen szer, a rofecoxib neve alapján „coxiboknak” nevezték el) között azonban számos, nem „coxibnak” nevezett szer, például a diclofenac (3. ábra) szelektivitása nagyobb a COX-2-höz, mint a COX-1-hez képest, és erősebb, mint a celecoxibé (8).

Az NSAID-kezelés kockázatainak részleteit illetően a korábbi közleményekre $(1-7,9)$ utalok. A cardiovascularis és gastrointestinalis kockázatot és ezen események (myocardium infarktus, szívelégtelenség, thrombosis, pitvarfibrilláció, illetve GI vérzés, ulcus, perforáció, pancreatitis, máj- és vesekárosodás) gyakoriságát növelő hatás hátterében többek között az áll, hogy a COX-2 gátlói nem csökkentik a thrombocyta-aggregációt $(1,3$, 10), gátolják a vasodilatator prosztaglandinok (PGE-2 és PGI-2) képződését, és emiatt fokozódik a tromboxán A-2 (TXA-2) termelódése és csökken a gasztroprotekció. Emellett növelik a vérnyomást, csökkentik az angiogenesist, destabilizálják az atheroscleroticus plakkokat, és gátolják az acetilszalicilsav protektív hatását. Az utóbbi hatásban is eltérés mutatkozott a különböző NSAID-ok között: az ibuprofen és naproxen gátolta, míg a meloxicam és etoricoxib nem befolyásolta az acetilszalicilsav thrombocyta-aggregációt gátló hatását (11-17). Az NSAID-ok gátolják néhány antihipertenzív szer (RAS-gátlók, $\beta$-blokkolók, diuretikumok) hatását is $(1,5,18)$. 


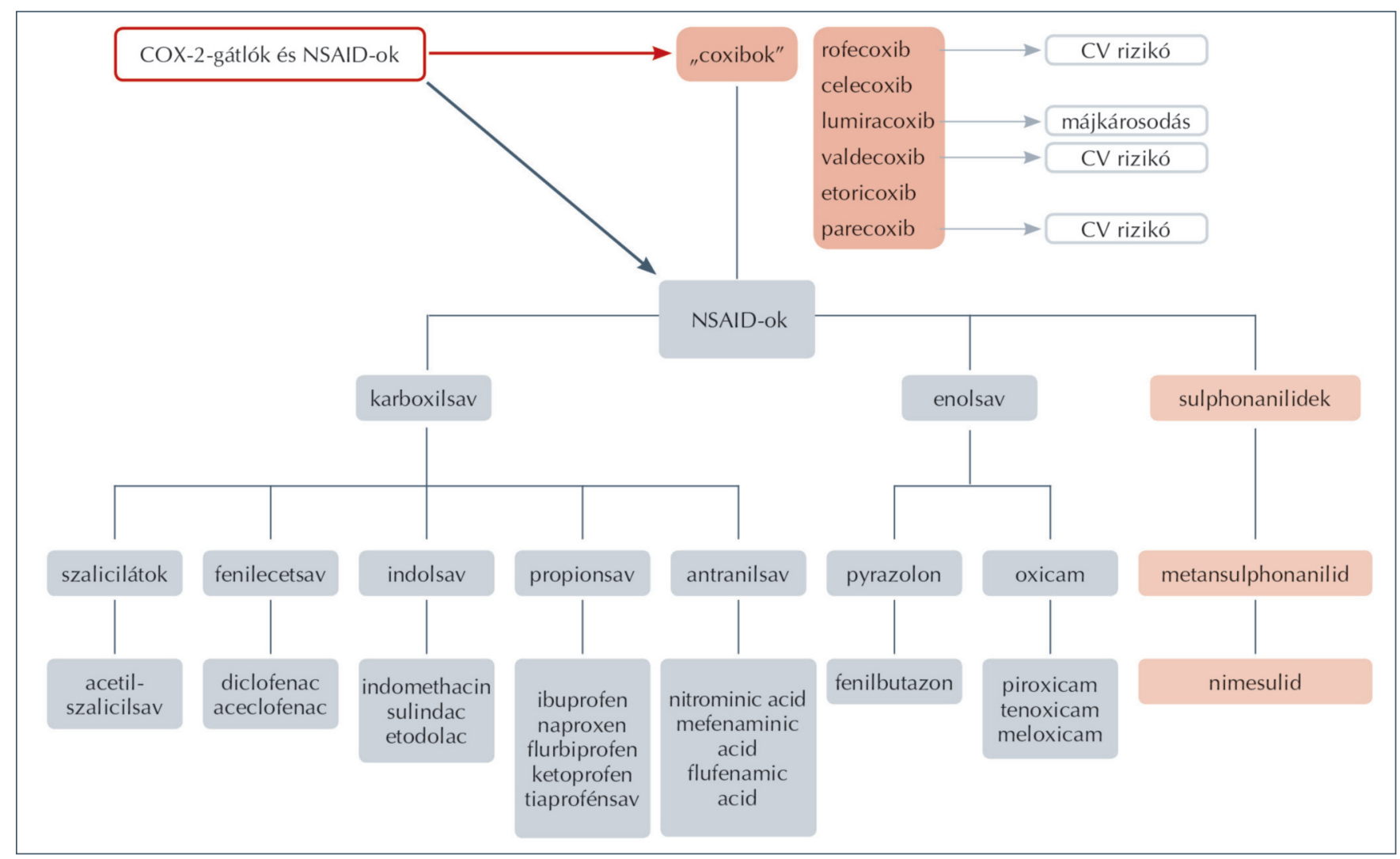

2. ábra. A COX enzimeket gátló szerek kémiai struktúrája

A 24081 osteoarthritises (OA-) vagy rheumatoid arthritises (RA-) beteg bevonásával végzett kettős vak, randomizált PRECISION vizsgálatban összehasonlították a celecoxib, a naproxen és az ibuprofen cardiovascularis, gastrointestinalis és renalis károsító hatását. Az OA-betegekben a celecoxib kezeléskor a cardiovascularis események kockázata nem tért el a naproxennel kezeltekétől, de kisebb volt, mint az ibuprofen alkalmazásakor. Az RA-betegekben viszont nem volt szignifikáns különbség a három terápiás csoportban tapasztalt CV kockázatban. Ezzel szemben a GI mellékhatásokban jelentős különbség mutatkozott a háromféle gyógyszerrel kezelt betegcsoport összehasonlításakor. A GI kockázat a celecoxibbal kezeltekben szignifikánsan kisebb volt, mint a naproxennel, vagy az ibuprofennel kezeltekben. A celecoxibbal kezeltekben a renalis nemkívánatos események kockázata szignifikánsan kisebb volt, mint az ibuprofennel kezeltekben. Fontos megjegyezni, hogy a celecoxibbal kezelt rheumatoid arthritises betegekben a mortalitás szignifikánsan kisebb volt, mint a naproxennel kezeltekben (19). A vizsgálathoz fưzött vélemény szerint - figyelembe véve a PRECISION vizsgálat gyengéit (például sokan idő előtt abbahagyták a vizsgálatot) -, ha lehetsé-

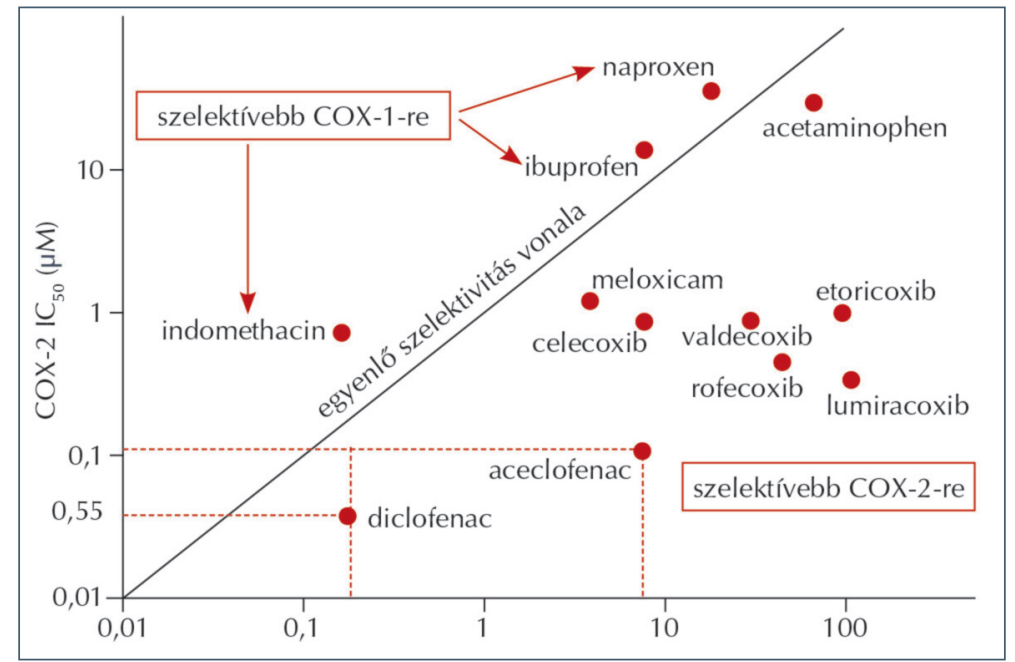

3. ábra. A COX-1-és COX-2-gátlás arány az a koncentráció, amely a COX-1 és COX-2 aktivitását 50\%-kal gátolja $\left(I C_{50}\right)$

ges, akkor a nagy CV kockázatú betegekben az NSAID-kezelést a lehetô legrövidebb ideig és a még hatásos legkisebb dózissal kell alkalmazni, mert a kockázat arányos a kezelés időtartamával és az alkalmazott dózissal (20).

A PRECISION vizsgálat adatait alátámasztja az, hogy a több mint 100000 myocardialis 


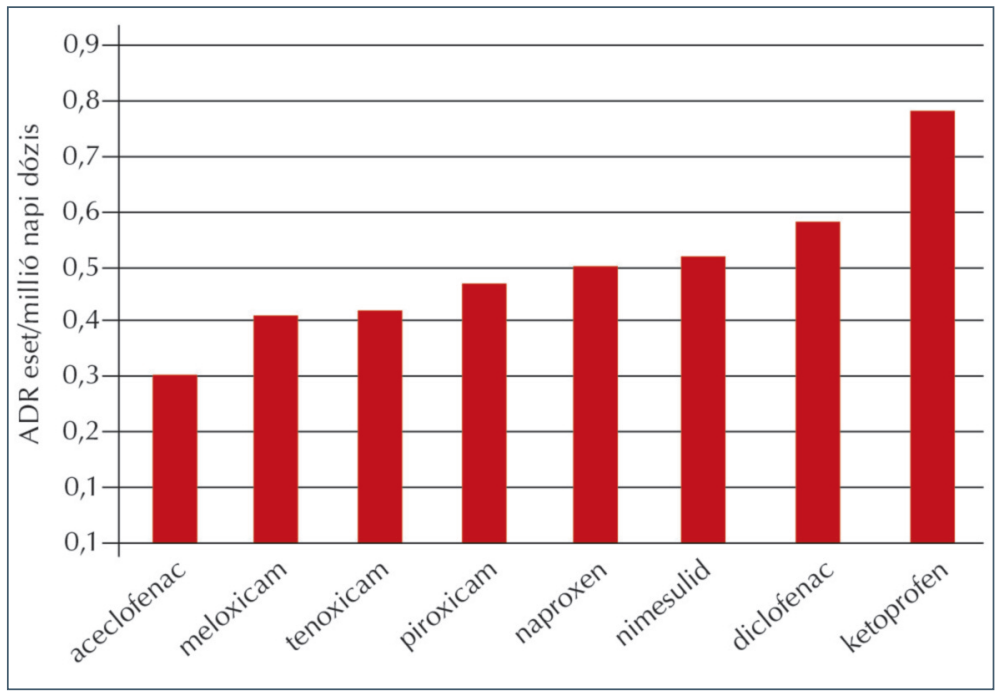

4. ábra. Súlyos mellékhatások (ADR) előfordulása különböző NSAIDhatóanyagok alkalmazásakor (32)

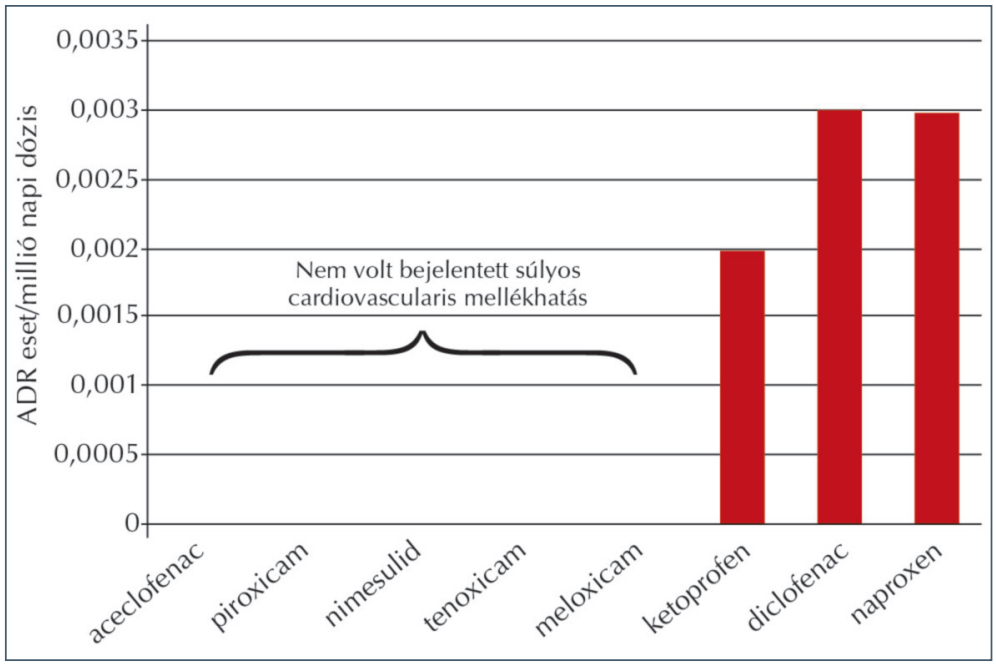

5. ábra. Súlyos cardiovascularis mellékhatások (ADR) előfordulása különböző NSAID-batóanyagok alkalmazásakor (32)

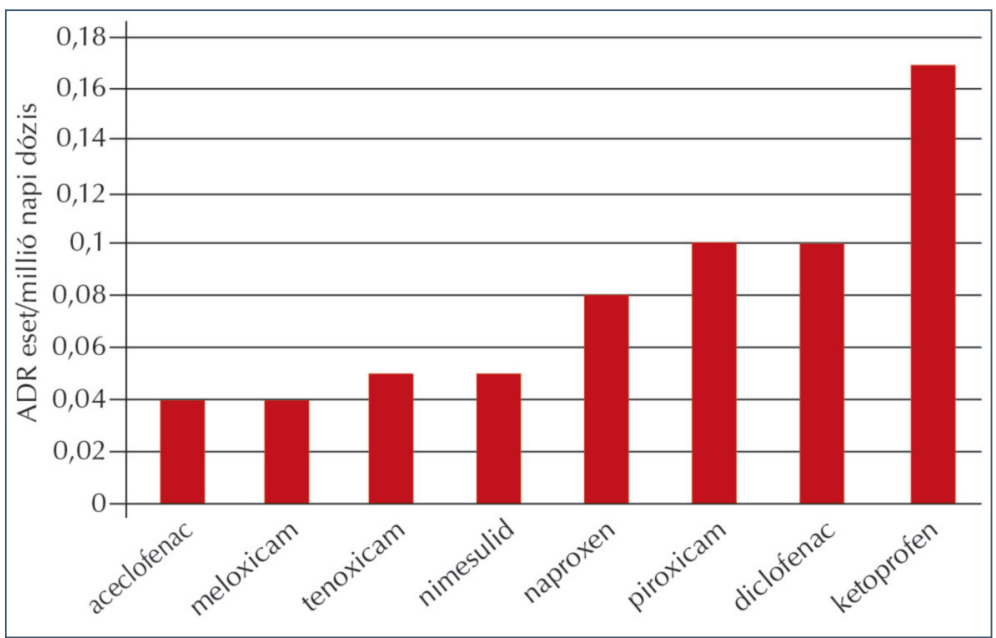

6. ábra. Súlyos gastrointestinalis mellékhatások $(A D R)$ előfordulása különböző NSAID-hatóanyagok alkalmazásakor (32) infarktuson átesett beteg 2,3 éves utánkövetése során azt tapasztalták, hogy a celecoxibhoz vagy a meloxicamhoz hasonlítva a naproxen terápia esetén a cardiovascularis és a gastrointestinalis kockázat szignifikánsan nagyobb volt (21).

A Covid-19-ben szenvedő betegek NSAIDdal történó kezeléséról szóló, 2020-ban megjelent NICE- (National Institute of Clinical Excellence) javaslatok is megegyeznek a fenti véleménnyel $(22,23)$.

\section{Aceclofenac}

Az aceclofenac kémiai szerkezete alapján (2-[2[2-[(2,6-diklorofenil)amino]fenil] acetil] oxiecetsav) az NSAID-csoportba tartozó szer. A szerkezetében levő hasonlóság ellenére hatásaiban jelentôsen eltér a diclofenacétól, gyulladásgátló hatása erôsebb annál (24), mert a ciklooxigenáz enzimet gátló effektusa mellett egyéb, a gyulladásban szerepet játszó citokinek hatását is gátolja. Következésképpen csökkenti a PGE-2 termelődését, csökkenti a neutrophil granulocyták migrációját és adhézióját azáltal is, hogy csökkenti az adhéziós molekulák expresszióját (VCAM, ICAM). Mindemellett jelentős antioxidáns hatása is van. A COX-2-t erősebben gátolja, mint a COX-1-et, ez a GI mellékhatások tekintetében számos vizsgálattal igazolt szignifikáns előnyt jelent (25-28), ezért a betegek terápiahưsége is igen jó (29). Egyéb NSAID-dal (piroxicam, tenoxicam, diclofenac, naproxen, ketoprofen, indomethacin) összehasonlítva jobb biztonságossági paramétereket (beleértve a GI mellékhatásokat is) tapasztaltak $(30,31)$.

Eddig 28 fázis III. klinikai vizsgálat történt aceclofenackal, melyekben nem csak GI, hanem egyéb típusú biztonságossági adatokat, illetve mellékhatásokat is ismertettek. A CV mellékhatásokra vonatkozólag ezekból a vizsgálatokból lehet következtetéseket levonni. A vizsgálatok időtartama széles határok között (15 nap - 24 hónap) ingadozott. Ezekben a vizsgálatokban aceclofenackal kezeltek 2656 beteget. Egyéb NSAID-dal összehasonlítás 1902 betegben történt: diclofenackal 756 betegben, naproxennel 276 betegben, piroxicammal 117 betegben, tenoxicammal 285 betegben, indomethacinnal 386 betegben, ketoprofennel 82 betegben.

Összesen 16 randomizált, összehasonlító vizsgálat eredményeit publikálták. Ezekben placebóval, illetve aktív szerrel (diclofenackal, naproxennel, piroxicammal, tenoxicammal, indomethacinnal, ketoprofennel) történt összehasonlítás. A felső GI vérzés kockázata a ketorolac esetében volt a legnagyobb, ezt követte az indomethacin, napro- 
xen, acetilszalicilsav, rofecoxib, meloxicam, dexketoprofen, diclofenac, nimesulid, ibuprofen, aceclofenac és a celecoxib $(21,25-29)$.

A nagyszámú beteg adatainak Lancetben publikált analízise (30) is rámutatott az NSAID-ok GI szövődményeire (vérzés, perforáció, elzáródás). A vizsgált összes NSAID szignifikánsan fokozta a GI kockázatot, közöttük a coxibok (OR: 1,81), a diclofenac (OR: 1,89), az ibuprofen (OR: 3,97) és a naproxen (OR: 4,22) is.

A Franciaországban 2002-2006 között összegyújtött mellékhatás-bejelentések (pharmacovigilance) adatai (32) alapján - noha ezek nem tekinthetők a klasszikus értelemben „kemény végpontoknak" - érdemes összefoglalni az adatokat (4-7. ábra).

\section{Következtetések}

1. A publikációk alapján súlyos mellékhatást legritkábban az aceclofenac, leggyakrabban a diclofenac és a ketoprofen alkalmazásakor jelentettek.

2. Úgy tûnik, hogy a CV rendszert érintő gyógyszermellékhatások gyakorisága és súlyossága az NSAID esetében nem függ a COX-1/COX-2 gátlás arányától.

3. Renalis mellékhatást legritkábban az aceclofenac, ennél több alkalommal a meloxicam, a piroxicam és a naproxen, leggyakrabban a diclofenac és a ketoprofen esetén jelentettek.

4. A GI mellékhatások gyakorisága a COX-2re szelektívebb NSAID-ok esetén általában ritkább és enyhébb, azonban kivételt képez az acec-

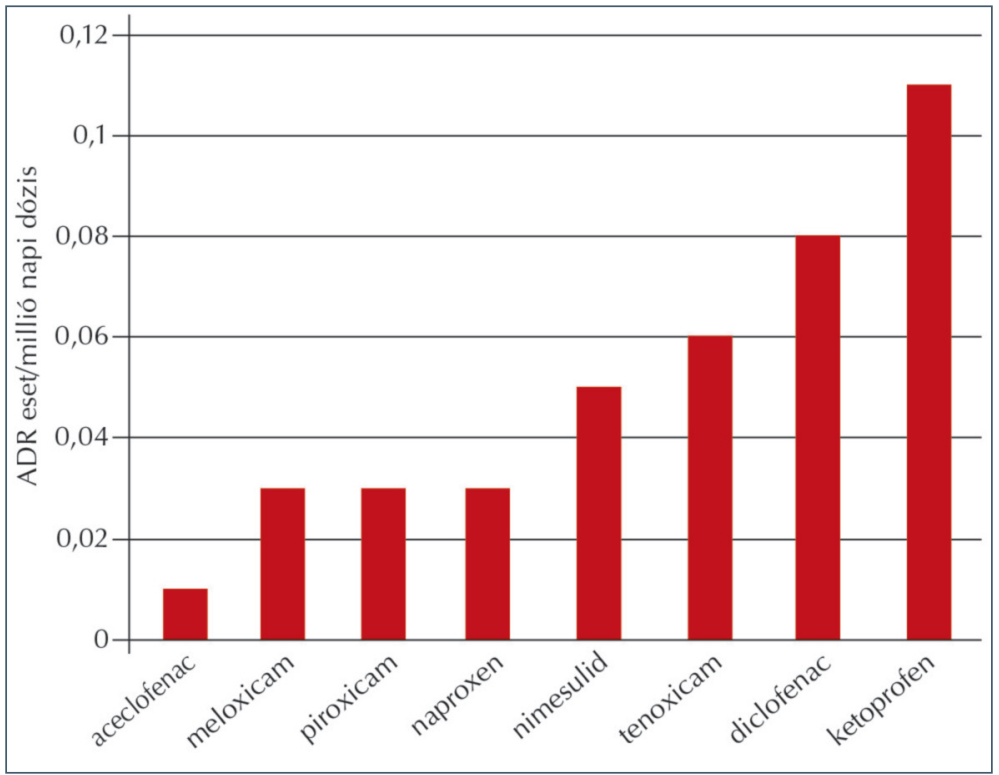

7. ábra. Súlyos renalis mellékhatások $(A D R)$ elôfordulása különbözó NSAID hatóanyagok alkalmazásakor (32)

lofenac, amely nem tekinthető COX-2 jelentôsen szelektív gyógyszernek, azonban az egyéb, pleiotrop hatásai következtében a GI rendszert érintô nemkívánatos hatásai ritkák és enyhék.

5. Mindezek alapján egyet kell értenünk a hatósági irányelvekkel (FDA, EMA, OSGI, OGYÉI), hogy az NSAID-kezelést a lehetô legrövidebb ideig és a legkisebb adaggal kell folytatni. Nincs meggyőző bizonyíték arra vonatkozóan, hogy a CV kockázat növelése tekintetében létezne a többinél kedvezőbb NSAID szer (33).

\section{Irodalom}

1. Farsang Cs. A nem szteroid gyulladáscsökkentók cardiovascularis kockázata. LAM 2011;21:249-55.

2. Farsang Cs. A nem szteroid gyulladáscsökkentôk kockázata. LAM 2012;22:95-100.

3. Farsang $C S$, Bedros JR, Alföldi $S$. A nem szteroid gyulladáscsökkentôk hipertenzív és cardiovascularis kockázatai. Hypertonia és Nephrologia 2012;16(1).

4. Farsang Cs, Bedros JR, Alföldi $S$. A nem szteroid gyulladáscsökkentôk kockázatai. LAM 2014;24:15-38.

5. Farsang Cs. Risks of nonsteroidal antiinflammatory drugs (NSAIDs). J Hypertens Res 2015;1(2):76-80.

6. Sütố G. Nemszteroid gyulladáscsökkentô szerek a mozgásszervi fájdalom csillapításában. Orv Hetil 2019;160: 855-60. https://doi.org/10.1556/650.2019.31502

7. Gáti T. NSAID-alkalmazás 65 év fölöttieknél. PharmaOnline 2020.

8. Warren TD, Michel JA. COX-selectivity of nonsteroidal inatiinflammatory drugs. FASEB 2014;18:790-804.

9. Sudano I, Flammer AJ, Roas S, Enseleit F, Noll G, Ruschitzka F. Nonsteroidal antiinflammatory drugs, acetaminophen, and hypertension. Curr Hypertens Rep 2012;14:304-9. https://doi.org/10.1007/s1 1906-012-0274-7
10. Szántó S. Biztonságos gyulladáscsökkentés. Fókuszban a szív- és érrendszeri rizikók. Háziorvosi Továbbképzó Szemle 2019;24:(Különkiadás):H6-H9.

11. Pope JE, Anderson JJ, Felson DT. A meta-analysis of the effects of nonsteroidal anti-inflammatory drugs on blood pressure. Arch Intern Med 1993;153:477-84. https://doi.org/10.1001/archinte.1993.00410040045007 https://doi.org/10.1001/archinte.153.4.477

12. Whelton $A$, White $W B$, Bello $A E$, et al. Effects of celecoxib and rofecoxib on blood pressure and edema in patients $\geq 65$ years of age with systemic hypertension and osteoarthritis. Am J Cardiol 2002;90:959-63. https://doi.org/10.1016/S0002-9149(02)02661-9

13. Howard PA, Delafontaine $P$. Nonsteroidal anti-inflammatory drugs and cardiovascular risk. I Am Coll Cardiol 2004;43:519-25.

https://doi.org/10.1016/j.jacc.2003.09.043

14. Konstam MA, Weir MR, Reicin A, et al. Cardiovascular thrombotic events in controlled, clinical trials of rofecoxib. Circulation 2001;104:2280-8.

https://doi.org/10.1161/hc4401.100078

15. Solomon DH, Glynn RJ, Levin R, Avorn J. Nonsteroidal 
anti-inflammatory drug use and acute myocardial infarction. Arch Intern Med 2002;162:1099-104 https://doi.org/10.1001/archinte.162.10.1099

16. Strand V, Hochberg MC. The risk of cardiovascular thrombotic events with selective cyclooxygenase-2 inhibitors. Arthritis Rheum 2002;47:349-55. https://doi.org/10.1002/art.10560

17. Meek IL, Vonkeman HE, Kasemier J, Movig KL, et al. Interference of NSAIDs with the thrombocyte inhibitory effect of aspirin: A placebo-controlled, ex vivo, serial placebocontrolled serial crossover study. Eur J Clin Pharmacol 2013;69:365-71.

https://doi.org/10.1007/s00228-012-1370-y

18. Gualtierotti R, Zoppi A, Mugellini A, et al. Effect of naproxen and acetminophen on blood presure lowering by ramipril, valsartan and aliskiren in hypertensive patients. Expert Opinion On Pharmacotherapy 2013;14:1875-84. https://doi.org/10.1517/14656566.2013.816286

19. Kang DO, An H, Park GU, Yum Y, Park EJ, Park Y, et al. Cardiovascular and bleeding risks associated with nonsteroidal anti-inflammatory drugs after myocardial infarction. J Amer Coll Cardiol 2020;76. https://doi.org/10.1016/j.jacc.2020.06.017

20. NICE advise: COVID-19 rapid evidence summary: acute use of non-steroidal anti-inflammatory drugs (NSAIDs) for people with or at risk of COVID-19. 14 April, 2020. www.nice.org.uk/guidance/es23

21. NICE evidence review: Acute use orf nonsteroidal antiinflammatory drugs (NSAIDs) for people with or at risk of COVID-19. April, 2020

22. Kang H-J, Oh I-Y, Chung J-W, et al. Effects of Celecoxib On Restenosis after coronary intervention and Evolution of Atherosclerosis (Mini-COREA) trial: celecoxib, a doubleedged sword for patients with angina. Eur Heart $J$ 2012;33:2653-61. https://doi.org/10.1093/eurheartj/ehs001

23. Gualtierotti R, Zoppi A, Mugellini A, et al. Effect of naproxen and acetaminophen on blood pressure lowering by ramipril, valsartan and aliskiren in hypertensive patients. Expert Opinion On Pharmacotherapy 2013;14:1875-84. https://doi.org/10.1517/14656566.2013.816286

24. Coxib and traditional NSAID Trialists' (CNT) Collaboration. Vascular and upper gastrointestinal effects of nonsteroidal anti-inflammatory drugs: meta-analyses of indivi- dual participant data from randomised trials. Lancet 2013; pii: S0140-6736(13)60900-9.

25. Krijthe BP, Heeringa J, Hofman A. et al. Non-steroidal anti-inflammatory drugs and the risk of atrial fibrillation: a population-based follow-up study. BMJ Open 2014;4:e 004059.

https://doi.org/10.1136/bmjopen-2013-004059

26. Kohli $P$, Steg $G$, Cannon CP et al on behalf of the REACH Registry Investigators. NSAID use and association with cardiovascular outcomes in outpatients with stable atherothrombotic disease. Am J Med 2014;127:53-60. https://doi.org/10.1016/j.amimed.2013.08.017

27. Lapi F, Azoulay L, Yin H, et al. Concurrent use of diuretics, angiotensin converting enzyme inhibitors, and angiotensin receptor blockers with non-steroidal anti-inflammatory drugs and risk of acute kidney injury: nested case-control study. BMJ 2013. Available at: http://www.bmi.com. https://doi.org/10.1136/bmj.e8525

28. Nitsch $D$, Tomlinson LA. Safety of coprescribing NSAIDs with multiple antihypertensive agents. BMJ 2013. Available at: http://www.bmj.com https://doi.org/10.1136/bmi.e8713

29. Laporte JR, Ibáñez L, Vidal X, et al. Upper gastro-intestinal bleeding associated with the use of NSAIDs New vs. older agents. Drug Safety 2004;27:411-20. https://doi.org/10.2165/00002018-200427060-00005

30. Colin Baigent, et al. Vascular and upper gastrointestinal effects of non-steriodal anty-inflammatory drugs: metaanalyses of individual participant data from randomised trials. Lancet 2013;382:769-79. https://doi.org/10.1016/S0140-6736(13)60900-9

31. Nagata N, Niikura $R$, Aoki $T$, et al. Colonic diverticular hemorrhage associated with the use of NSAIDs, low-dose aspirin, antiplatelet drugs, and dual therapy. J Gastroenterol Hepatol 2014. https://doi.org/10.1111/jgh.12595

32. Lapeyre-Mestre M, Grolleau S, Montastruc JL. Adverse drug reactions associated with the use of NSAIDs: a case/noncase analysis of spontaneous reports from the French pharmacovigilance database 2002-2006. Fundam Clin Pharmacol 2013;27:223-30. https://doi.org/10.1111/j.1472-8206.2011.00991.x

33. FDA Advisory Panels Vote Against CV Safety Claim for Naproxen. February 11, 2014

\section{GONDOLATOK A LAM-BÓL I 30 ÉVE ÍRTÁK}

\section{"REFORM ROVAT}

\section{Túl vagyunk a rendszerváltáson?}

Az egészségüggyel kapcsolatba kerülő polgárok remélték, hogy a rendszerváltás - ba nem is azonnal - belyzetükön javítani fog.

Ma azonban az tapasztalható, hogy a feszültségek növekszenek, a lehetôségek beszúkülnek, a horizont szúkül.

Ilyen helyzetben jelenik meg a csodavárás és a csodálatos megoldások kínálása. A panaceára gyorsan, mondhatni azonnal lenne szükség. Sajnos a csodákra jellemzó, hogy az adott belyzettöl, körülményektól függetlenül, azoknak fittyet hányva jönnek létre, és rövid életüek.

A gyors változásokat javaslók jószándéka aligha vitatható. Többségükben minden bizonnyal az elmúlt évek rossz tapasztalatai, a korábbi struktúra falai gerjesztették a dühöt. $E$ döhös emberek közül sokan azonban nem voltak és ma sincsenek abban a helyzetben, hogy az egészségügyi ellátás minden szférájának minden szintjét, múködését, kapcsolatrendszerét átlássák."

Bondár É., Weltner J.: Túl vagyunk a rendszerváltáson? Lege Artis Medicinæ, Próbaszám 1990;(1):46-48. 